OPEN

SUBJECT AREAS: ELECTROCHEMISTRY BATTERIES

Received

6 September 2014

Accepted

15 October 2014

Published

5 November 2014

Correspondence and requests for materials should be addressed to Y.W. lygwang@ fudan.edu.cn)

\title{
Re-building Daniell Cell with a Li-ion exchange Film
}

\author{
Xiaoli Dong, Yonggang Wang \& Yongyao Xia
}

Department of Chemistry and Shanghai Key Laboratory of Molecular Catalysis and Innovative Materials, Institute of New Energy, Fudan University, Shanghai 200433, China.

Daniell cell (i.e. Zn-Cu battery) is widely used in chemistry curricula to illustrate how batteries work, although it has been supplanted in the late 19th century by more modern battery designs because of $\mathrm{Cu}^{2+}$-crossover-induced self-discharge and un-rechargeable characteristic. Herein, it is re-built by using a ceramic $\mathrm{Li}$-ion exchange film to separate $\mathrm{Cu}$ and $\mathrm{Zn}$ electrodes for preventing $\mathrm{Cu}^{2+}$-crossover between two electrodes. The re-built $\mathrm{Zn}-\mathrm{Cu}$ battery can be cycled for 150 times without capacity attenuation and self-discharge, and displays a theoretical energy density of $68.3 \mathrm{Wh} \mathrm{kg}^{-1}$. It is more important that both electrodes of the battery are renewable, reusable, low toxicity and environmentally friendly. Owing to these advantages mentioned above, the re-built Daniell cell can be considered as a promising and green stationary power source for large-scale energy storage.

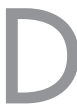

aniell cell, invented by the British chemist John Frederic Daniell in 1836, is popularly known as a kind of zinc-copper battery which takes advantage of a porous barrier between the two metals ${ }^{1,2}$. Once used widely in the European telegraph industry, it was supplanted in the late 19th century by more modern battery designs. Today, it is primarily used in the chemistry curricula to demonstrate how batteries work ${ }^{1,2}$. As shown in our chemistry curricula, the typical Daniell cell works with a salt bridge connecting the anode electrode of a zinc sulfate solution and an immersed zinc plate as well as the cathode electrode of a copper sulfate solution and an immersed copper plate (Figure S1). When discharged, the anode of zinc will be oxidized according to the equation 1 :

$$
\mathrm{Zn}_{(\mathrm{s})} \rightarrow \mathrm{Zn}^{2+}{ }_{(\mathrm{aq})}+2 \mathrm{e}^{-}
$$

At the same time, the cathode of copper ions will be reduced following the equation 2 :

$$
\mathrm{Cu}^{2+}{ }_{(\mathrm{aq})}+2 \mathrm{e}^{-} \rightarrow \mathrm{Cu}_{(\mathrm{s})}
$$

Therefore, we can see the total reaction as $[\mathrm{Zn}(\mathrm{s})]+\left[\mathrm{Cu}^{2+}(\mathrm{aq})\right] \rightarrow\left[\mathrm{Zn}^{2+}(\mathrm{aq})\right]+[\mathrm{Cu}(\mathrm{s})]$ during the discharge course. These two processes cause copper solid to accumulate at the cathode and the zinc electrode to dissolve into the solution and show a theoretical potential of $1.1 \mathrm{~V}$ at $25^{\circ} \mathrm{C}$. Without the salt bridge, the reaction will occur directly (i.e. Cu will be deposited on $\mathrm{Zn}$ anode) and the electron flow will not be directed through the outer wire to supply power for use. To be exactly, the cations in the salt bridge migrate to the container containing the copper electrode to replace the copper ions being consumed, while the anions in the salt bridge migrate toward the zinc side, where they keep the solution containing the newly formed zinc cations electrically neutral. However, it is a pity to realize that the salt bridge (or porous barrier) can only alleviate the $\mathrm{Cu}^{2+}$ crossover. At the open circuit condition, $\mathrm{Cu}^{2+}$ still can slowly diffuse from the $\mathrm{Cu}$ electrode room to $\mathrm{Zn}$ electrode room through the salt bridge (or porous barrier), and then the $\mathrm{Cu}^{2+}$ is reduced into metallic $\mathrm{Cu}$ on the surface of $\mathrm{Zn}$ electrode, indicating a serious self-discharge and/or suicide process (see Figure S2 for detail). It is also undoubted that Daniell Cell is not rechargeable, because recharge would much aggravate the $\mathrm{Cu}^{2+}$ crossover, indicating a battery-killing process (see Figure S3 for detail).

Owing to the serious self-discharge and the unrechargeable characteristic, Daniell cell was supplanted by more modern rechargeable battery technologies, such as Lead-acid battery developed in 1859, Ni-Cd (Nickel/ Cadmium) battery developed in 1909, Ni-MH (Nickel/Metal hydride) battery developed in 1975 and Li-ion battery developed in $1990^{3}$. Up to present, these aqueous-electrolyte-based rechargeable batteries (i.e. Lead-acid, $\mathrm{Ni}-\mathrm{Cd}$ and Ni-MH, etc.) and the organic-electrolyte-based Li-ion batteries are still used for diverse range of applications ${ }^{3,4}$. Due to their higher energy density and cycling stability, the Li-ion batteries using two intercalated compounds (e.g. carbon anode and $\mathrm{LiCoO}_{2}$ cathode) in an organic solution electrolyte occupy the main market of 
battery, and are widely used for various electronic devices, from portable devices (such as cellular phones, notebook-size personal computers, and so on) to electric vehicles (EVs) ${ }^{3,4}$.

Owing to the accelerated energy consumption and aggravated global warming, it is undoubted that future economy must be based on green and sustainable energy source, such as solar energy, wind energy, etc. As a result, utilization of these sustainable energy sources has been a hot topic. It is well known that the efficient utilization of these sustainable energy sources depends on large-scale stationary energy storage batteries. However, the organic-electrolyte-based Liion battery is difficult to play the role of large-scale energy storage device for these sustainable energy sources. Despite the remarkable performance of these organic based systems mentioned above, they suffer from the use of highly toxic and flammable solvents, which can cause safety hazards if used improperly, such as overcharging or short-circuiting ${ }^{3,4}$. Especially, numerous lithium-ion battery accidents causing fires and explosions have been reported. As a response, these high safety aqueous rechargeable batteries should be the promising candidates for large-scale energy storage, although they display lower energy density. Unfortunately, the application of these commercialized aqueous rechargeable batteries (i.e. Lead-acid, Ni-Cd and $\mathrm{Ni}-\mathrm{MH}$, etc.) in large-scale energy storage may be held back by the toxicity of electrode materials (such as $\mathrm{Pb}$ and $\mathrm{Cd}$ ) and/or limited storage of raw materials for electrode (such as Metal hydride). Therefore, aqueous electrolyte Li-ion batteries arrest much attention in recent years, despite their poor cycling stability ${ }^{5,6}$. However, the raw materials for intercalation compounds (i.e. electrode materials for Li-ion batteries) are not sustainable because cobalt, nickel, manganese and lithium must be natural resources. In addition, most intercalation compounds for Li-ion batteries are prepared by hightemperature solid-state reaction, which also results in consumption of energy and $\mathrm{CO}_{2}$ emission ${ }^{3}$. As we know, the carbon footprint of organic Li-ion batteries even reaches $70 \mathrm{Kg} \mathrm{CO}_{2}$ per $\mathrm{kWh}^{3}$. Especially, the reuse of these intercalation compounds in the used batteries is very difficult and complex. As a response, it may be the time for us to reconsider Daniell cell as a candidate for large-scale energy storage, because both $\mathrm{Zn}$ and $\mathrm{Cu}$ are low toxicity, renewable and reusable. However, the precondition is to well deal with the problem from $\mathrm{Cu}^{2+}$ crossover on operating process, which obviously is a great challenge.

Herein a ceramic lithium super-ionic conductor (LATSP, $\left.\mathrm{Li}_{1+\mathrm{x}+\mathrm{y}} \mathrm{Al}_{\mathrm{x}} \mathrm{Ti}_{2-\mathrm{x}} \mathrm{Si}_{\mathrm{y}} \mathrm{P}_{3-\mathrm{y}} \mathrm{O}_{12}\right)$ thin film, which is recently used in aqueous/non-aqueous double-electrolyte batteries ${ }^{7-23}$, was used to separate the $\mathrm{Cu}$ cathode and $\mathrm{Zn}$ anode to build a stable and rechargeable $\mathrm{Zn}-\mathrm{Cu}$ battery. The resulting $\mathrm{Zn}-\mathrm{Cu}$ battery can be cycled for 150 times without obvious capacity attenuation, and the open circuit voltage investigation shows that the potential can keep stable for over $100 \mathrm{~h}$ without any loss of the capacity.

\section{Results}

The structure and operating mechanism of the rechargeable $\mathrm{Zn}-\mathrm{Cu}$ battery are illustrated in Figure 1, where it can be detected that a $\mathrm{Cu}$ cathode $\left(1 \mathrm{~cm}^{2}\right)$ in $0.25 \mathrm{~mL} 2 \mathrm{M} \mathrm{LiNO}_{3}$ electrolyte solution and a $\mathrm{Zn}$ anode $\left(1 \mathrm{~cm}^{2}\right)$ in $0.25 \mathrm{~mL} 1 \mathrm{M} \mathrm{Zn}\left(\mathrm{NO}_{3}\right)_{2}$ electrolyte solution are separated by a ceramic LATSP film. Detailed information about the as-prepared rechargeable $\mathrm{Zn}-\mathrm{Cu}$ battery is given in Figure S4. On charge, metallic $\mathrm{Cu}$ (i.e. cathode) is oxidized into $\mathrm{Cu}^{2+}$ and the $\mathrm{Zn}^{2+}$ in anodic room is reduced into metallic $\mathrm{Zn}$ at the surface of anode, while Li ions in the cathodic room diffuse to the anodic room through the LATSP ceramic film to balance the charges. Simultaneously, electrons are transferred from $\mathrm{Cu}$ cathode to $\mathrm{Zn}$ anode through the outer circuit. Discharge reverses the charge process, and is similar with conventional Daniell cell. As a result, the total reaction within the developed rechargeable $\mathrm{Zn}$-Cu battery can be summarized as:

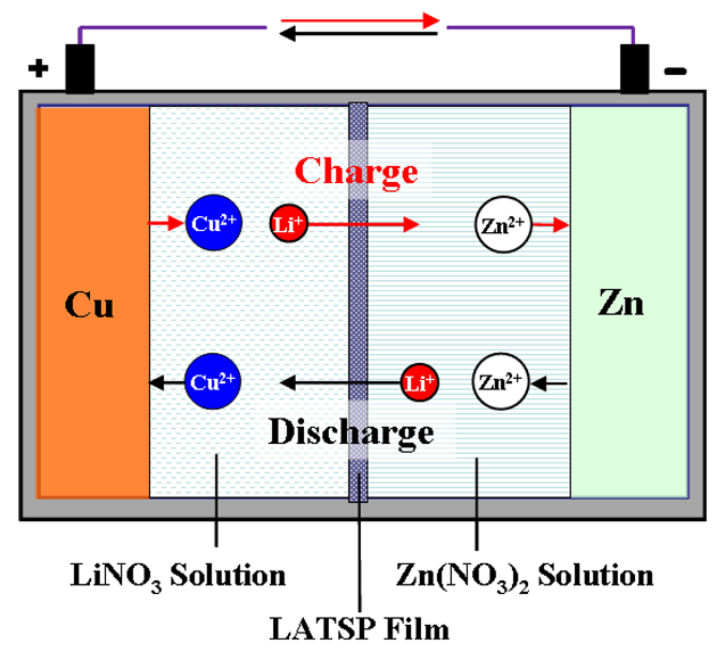

Figure 1 Schematic illustration and operating mechanism of rechargeable $\mathrm{Zn}-\mathrm{Cu}$ battery with a Li-ion exchange membrane.

$\left[\mathrm{Cu}+2 \mathrm{LiNO}_{3}\right]+\mathrm{Zn}\left(\mathrm{NO}_{3}\right)_{2} \leftarrow \rightarrow \mathrm{Cu}\left(\mathrm{NO}_{3}\right)_{2}+\left[2 \mathrm{LiNO}_{3}+\mathrm{Zn}\right]$

Figure 2 gives the cyclic profile of the rechargeable $\mathrm{Zn}$ - $\mathrm{Cu}$ battery with an applied current of $0.25 \mathrm{~mA}$. In this investigation, a battery is charged for 6 hours to reach a charge capacity of $1.5 \mathrm{mAh}$, and then the battery is discharged to $0.2 \mathrm{~V}$. As shown in Figure 2a, the battery displays a flat charge voltage of $1.25 \mathrm{~V}$ for 6 hours and a flat discharge voltage of about $0.8 \mathrm{~V}$ for about 6 hours with the applied current of $0.25 \mathrm{~mA}$. About $1.78 \mathrm{mg}$ metallic $\mathrm{Cu}$ is transformed into $\mathrm{Cu}^{2+}$ in cathodic room through the $6 \mathrm{~h}$ charge with a current of $0.25 \mathrm{~mA}$, and simultaneously $\mathrm{Zn}^{2+}$ in the electrolyte of anodic room is reduced into metallic $\mathrm{Zn}$. At the same time, Li-ions diffuse from cathodic room to anodic room to balance the charge. In order to further clarify the coulombic efficiency, we calculated the capacity ( $\mathrm{mAh} \mathrm{g}_{\mathrm{Cu}}{ }^{-1}$ ) based on the mass of consumed metallic $\mathrm{Cu}$ (or generated $\mathrm{Cu}^{2+}$ ) over charge process. As shown in Figure 2b, the achieved discharge capacity of $843 \mathrm{mAh} \mathrm{g}_{\mathrm{Cu}}{ }^{-1}$ is equal to the charge capacity at initial cycle. However, the discharge capacity at 20th, 75 th and 150th cycle is slightly smaller than corresponding charge capacity, indicating that the Coulombic efficiency of the $\mathrm{Zn}$-Cu battery is only close to $100 \%$. In other words, there is no obvious crossover of $\mathrm{Cu}^{2+}$ over charge-discharge process. Especially, the battery almost keeps the constant discharge voltage and capacity at various cycles, suggesting perfect cyclic ability (Figure $2 \mathrm{a}$ and $2 \mathrm{~b}$ ). The rechargeable characteristic should be attributed to that the ceramic Li-ion exchange film (i.e. LTASP) can efficiently prevent the $\mathrm{Cu}^{2+}$ crossover, which is confirmed by electrochemical impedance spectroscopic (EIS) investigation (Figure S5). Furthermore, it also should be noted that there is a clear degradation of the charge voltage curved at the beginning of the charging step. This phenomenon may be ascribed to the formation of $\mathrm{Cu}_{2} \mathrm{O}$ and the growth of dendrite on the surface of cathode, and need further investigation (see supplementary information for detailed discussion). Herein, we also employed a proton exchange membrane (Nafion 117) to separate the $\mathrm{Cu}$ cathode and $\mathrm{Zn}$ anode, and investigated its cyclic performance at the same experiment condition for comparison. Unfortunately, being similar to the saltbridge-based Daniell cell (Figure S3), the Nafion-film-based $\mathrm{Zn}-\mathrm{Cu}$ battery can not be recharged (Figure S6). Although the proton exchange membrane permits the fast pass of $\mathrm{Li}^{+}$, it also permits the pass of $\mathrm{Cu}^{2+}$ (See Figure S7 and corresponding discussion). In order to further clarify the stability of the rechargeable $\mathrm{Zn}$-Cu battery with a LTASP separator, self-discharge investigation of the battery was conducted. In this measurement, the battery was first charged for 10 hours with an applied current density of $0.1 \mathrm{~mA}$. Then, the 

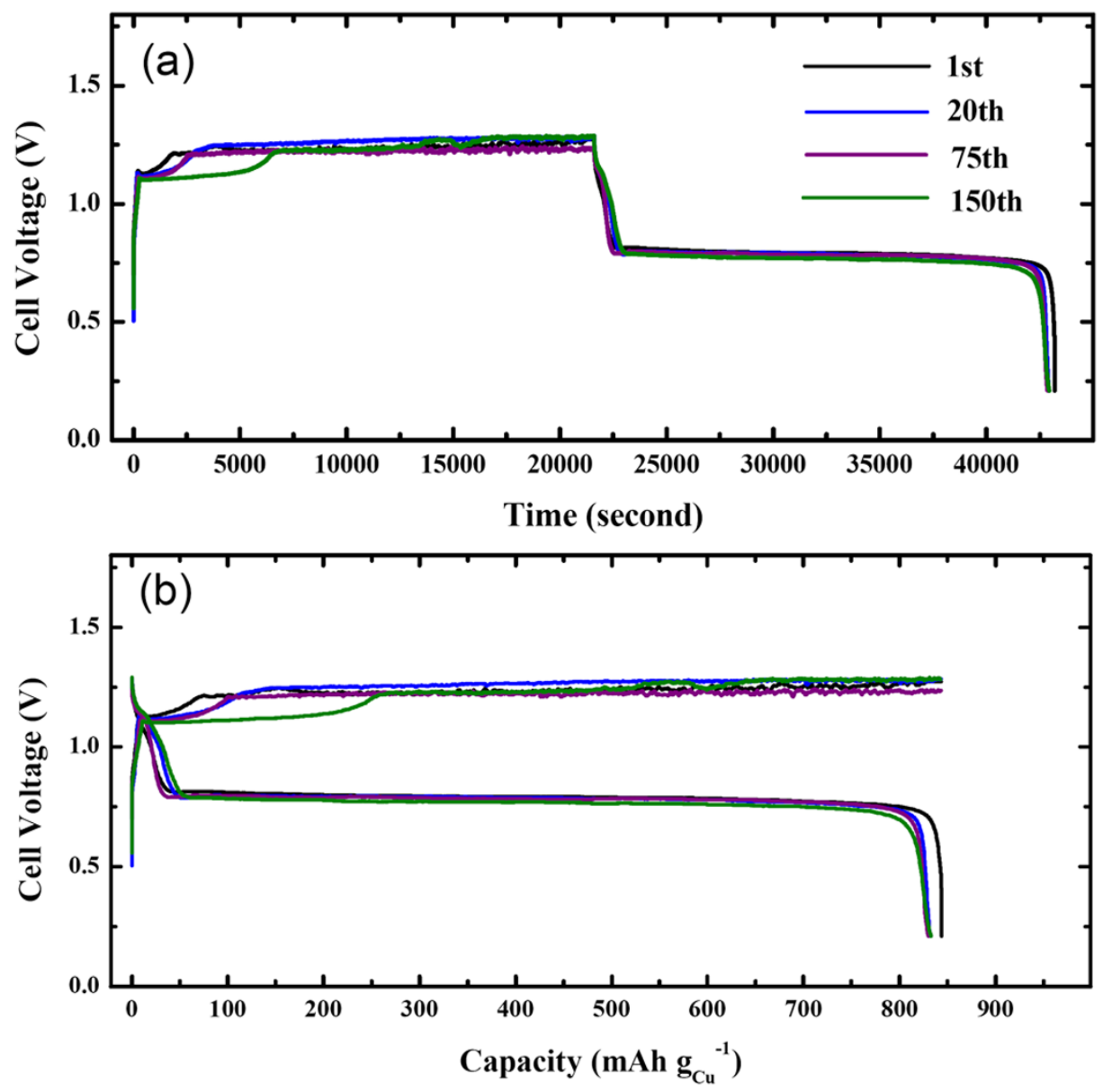

Figure $2 \mid$ Cyclic profile of the rechargeable $\mathrm{Zn}$-Cu battery. (a) Cell voltage vs. time. (b) Cell voltage vs. capacity. [In this investigation, a battery is charged for 6 hours to reach a charge capacity of $1.5 \mathrm{mAh}$, and then the battery is discharged to $0.2 \mathrm{~V}$ with an applied current of $0.25 \mathrm{~mA}$.]

charged battery was kept at open circuit voltage condition (OCV) for 100 hours (Figure 3a). Finally, the resulting battery was discharged with a current of $0.1 \mathrm{~mA}$ (Figure 3a). As shown in Figure 3b, the battery displays a flat discharge voltage for about 10 hours at the current of $0.1 \mathrm{~mA}$ (i.e. a discharge capacity of around $843 \mathrm{mAh}$ $\mathrm{g}_{\mathrm{Cu}}{ }^{-1}$ ), indicating that the generated $\mathrm{Cu}^{2+}$ has been converted into metallic $\mathrm{Cu}$ through the electrochemical reduction on discharge process. Herein, we also carried out a control study as a comparison where a $\mathrm{Zn}$-Cu battery was built in the same way as the one described for Figure $3 \mathrm{a}$, and was discharged without OCV storage at the same current of $0.1 \mathrm{~mA}$. In this measurement, the $\mathrm{Zn}$-Cu battery was first charged for 10 hours with an applied current density of $0.1 \mathrm{~mA}$, and then was discharged with a current of $0.1 \mathrm{~mA}$ without OCV storage. Discharge curve of the $\mathrm{Zn}$-Cu battery without OCV storage is given in Figure 3c, where it can be observed that the battery displays a flat discharge voltage for about 10 hours, indicating a capacity of around $843 \mathrm{mAh} \mathrm{g}_{\mathrm{Cu}}{ }^{-1}$. The comparison between Figure $3 \mathrm{~b}$ and $3 \mathrm{c}$ demonstrates that the conventional Daniell cell can be developed as a rechargeable $\mathrm{Zn}-\mathrm{Cu}$ battery without self-discharge. In addition, a small voltage plateau arising from the hydrogen evolution can be observed at the end of the discharge, indicating the charge/discharge efficiency does not reach $100 \%$.

Figure $4 \mathrm{a}$ gives the rate performance of the rechargeable $\mathrm{Zn}-\mathrm{Cu}$ battery using a LATSP separator. In this investigation, the battery was charged for $6 \mathrm{~h}$ with a current of $1 \mathrm{~mA}$, and then discharged with different currents. The capacities at different currents are also just calculated based on the mass of consumed $\mathrm{Cu}$ (or generated $\mathrm{Cu}^{2+}$ ) over charge process. As shown in Figure $4 \mathrm{a}$, the polarization increases obviously with the growth of discharge currents, suggesting a large internal resistance. Obviously, the low conductivity of LATSP will much limit the power output of this kind of LATSP-based $\mathrm{Zn}-\mathrm{Cu}$ battery. However, this drawback may be solved by adjusting the operating model of this kind of battery. It is well known that proton exchange membrane (i.e. Nafion film) is of high ionic conductivity. For instance, we also investigated the rate performance of Nafionbased $\mathrm{Zn}-\mathrm{Cu}$ battery at the same condition. In this investigation, a LATSP-based $\mathrm{Zn}$-Cu battery was first charged for 6 hours to form $\mathrm{Cu}^{2+}$ solution in the cathodic room. Then, the generated $\mathrm{Cu}^{2+}$ solution is removed to the cathodic room of a Nafion-based $\mathrm{Zn}-\mathrm{Cu}$ battery $(\mathrm{Zn} / \mathrm{Nafion} / \mathrm{Cu})$ for discharge measurement. Figure $4 \mathrm{~b}$ gives the discharge profile of the Nafion-based $\mathrm{Zn}$-Cu battery at different currents. It can be observed from Figure $4 \mathrm{~b}$ that the Nafion-based Zn-Cu battery displays higher operating voltage even at much higher discharge currents, compared with that of LATSP-based Zn-Cu battery. However, it should be noted that the discharge capacity is lower than the theoretical capacity (i.e. $843 \mathrm{mAh} \mathrm{g}_{\mathrm{Cu}}{ }^{-1}$ ) of metallic $\mathrm{Cu}$ (or $\mathrm{Cu}^{2+}$ ), indicating a small amount of $\mathrm{Cu}^{2+}$ crossover over discharge. Furthermore, it can be observed that an additional voltage plateau (about $0.4 \mathrm{~V}$ ) appears at the end of discharge of Nafion-based $\mathrm{Zn}-\mathrm{Cu}$ battery, which should be attributable to the $\mathrm{H}_{2}$ evolution over discharge process. According to the operating mechanism of the rechargeable $\mathrm{Zn}-\mathrm{Cu}$ battery (see Figure 1), Li ions should diffuse from anodic room to cathodic room to balance the charge over discharge process. However, the Nafion film also permits the fast pass of $\mathrm{H}^{+}$. As a result, the protons also diffuse from anodic room to cathodic room in parallel with the $\mathrm{Li}$ ions diffusion on discharge. The proton crossover improves the $\mathrm{H}^{+}$concentration in the cathodic room, and thus enhances the $\mathrm{H}_{2}$ evolution potential over discharge 

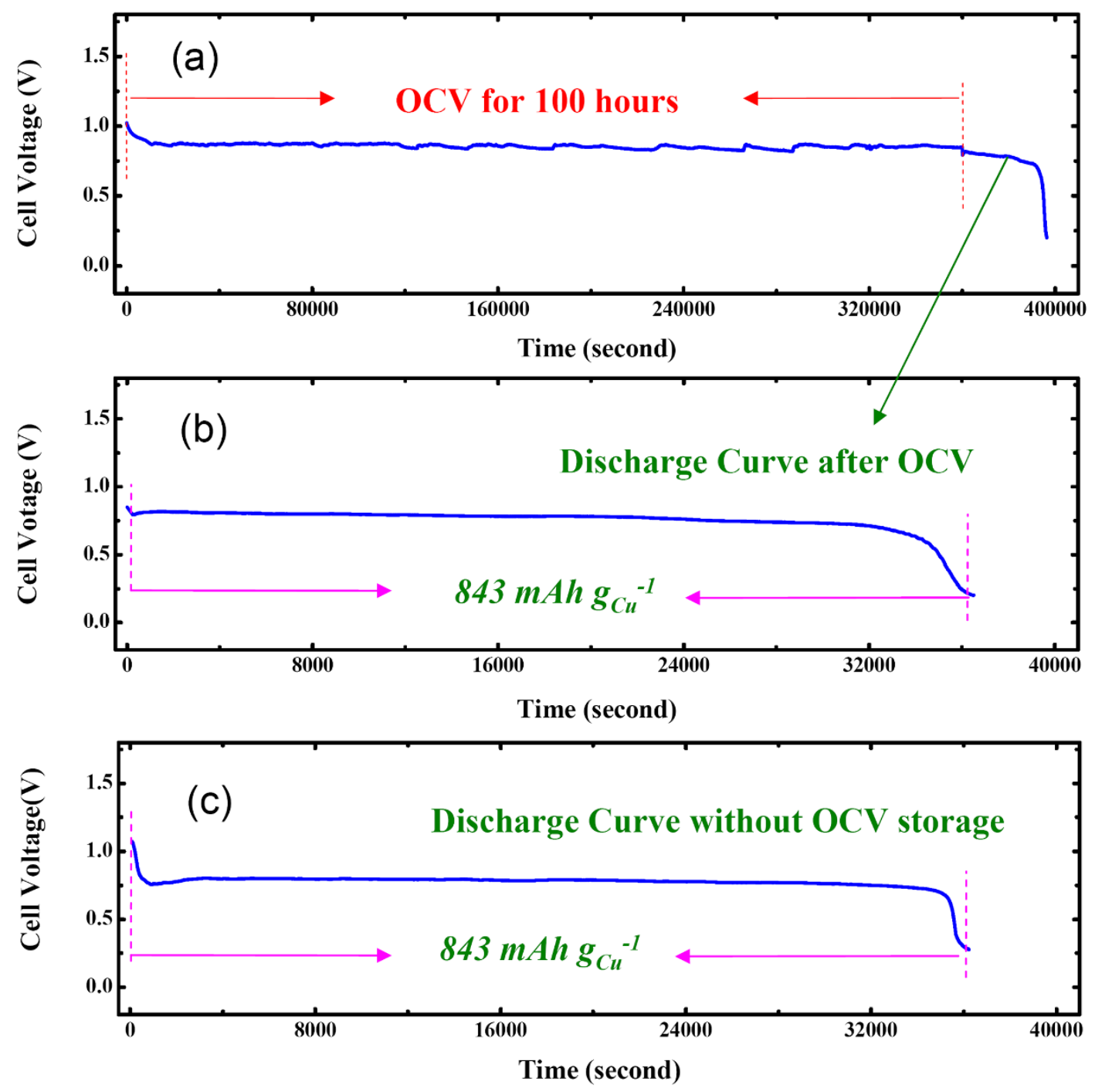

Figure 3 Self-discharge investigation of the rechargeable Zn-Cu battery. (a) OCV and discharge curves. (b) Enlargement of discharge curve after OCV test. (c) Discharge curve without OCV storage.

process. The results from Figure $4 \mathrm{a}$ and $4 \mathrm{~b}$ suggest that we can improve the power output of rechargeable $\mathrm{Zn}-\mathrm{Cu}$ battery through adjusting operating method. As shown in Figure 4c, the LATSPbased $\mathrm{Zn}-\mathrm{Cu}$ battery can be used for charge storage (i.e. to form $\mathrm{Cu}^{2+}$ solution and metallic $\mathrm{Zn}$ through charge process), and then the charge products (e.g. $\mathrm{Cu}^{2+}$ ) can be flowed to the Nafion-based $\mathrm{Zn}-\mathrm{Cu}$ battery for high rate discharge when high power output is needed. This technology may be similar with flow batteries. In order to further evaluate the power output of the rechargeable $\mathrm{Zn}-\mathrm{Cu}$ battery, higher concentration $\mathrm{Cu}\left(\mathrm{NO}_{3}\right)_{2}$ solution $(1 \mathrm{M})$ was employed as cathodic electrolyte to investigate the power performance of Nafion-based Zn-Cu battery and LATSP-based Zn-Cu battery, respectively. As shown in Figure 5, the discharge voltage of Nafion-based $\mathrm{Zn}$-Cu battery is still higher than $0.5 \mathrm{~V}$ even at the high current of $35 \mathrm{~mA}$ (i.e. $35 \mathrm{~mA} \mathrm{~cm}^{-2}$ ). However, the discharge voltage of LATSP-based $\mathrm{Zn}$-Cu battery reduces to $0.5 \mathrm{~V}$ at the current of $3 \mathrm{~mA}$ (see inset of Figure 5). The result from Figure 5 further confirms that Nafion-based $\mathrm{Zn}$-Cu battery can efficiently offset the low power characteristic of LATSP-based Zn-Cu battery.

\section{Discussion}

Above results have demonstrated that the new type $\mathrm{Zn}$-Cu battery is of perfect cyclic ability and high stability, and its power output can also be improved through proper operating method. As a result, the next logic step is to evaluate its theoretical energy density. It should be noted that the above capacity (i.e. $\mathrm{mAh}_{\mathrm{Cu}}{ }^{-1}$ ) calculated from the consumed $\mathrm{Cu}$ or $\mathrm{Cu}^{2+}$ is just used to describe the reversibility of battery, and thus can not be employed to evaluate the true energy density of the battery. According to Equation 3, the active materials of the new type $\mathrm{Zn}-\mathrm{Cu}$ battery include $\mathrm{Cu}, \mathrm{LiNO}_{3}$ and $\mathrm{Zn}\left(\mathrm{NO}_{3}\right)_{2}$. Furthermore, the solubility in water of $\mathrm{LiNO}_{3}$ and $\mathrm{Zn}\left(\mathrm{NO}_{3}\right)_{2}$ should also be considered in the calculation of energy density. Accordingly, the theoretical energy density of the rechargeable $\mathrm{Zn}-\mathrm{Cu}$ battery based on the total weight of the $\mathrm{Cu}$ cathode, the $\mathrm{LiNO}_{3}$ electrolyte and the aqueous $\mathrm{Zn}\left(\mathrm{NO}_{3}\right)_{2}$ anode can be calculated from equation (4)

$E=\frac{Q \times m_{c u} \times V}{m_{\text {cathode }}+m_{\text {electrolyte }}+m_{\text {anode }}}=\frac{Q \times m_{c u} \times V}{m_{\mathrm{Cu}}+\left(m_{\mathrm{LiNO}_{3}}+m^{1} \mathrm{H}_{2} \mathrm{O}\right)+\left(m_{\mathrm{Zn}\left(\mathrm{NO}_{3}\right)_{2}}+m^{2} \mathrm{H}_{2} \mathrm{O}\right)}(4)$

where $E$ is the energy density ( $\left.\mathrm{Wh} \mathrm{kg}^{-1}\right), V$ is the discharge voltage $(\sim 0.8 \mathrm{~V}), Q$ is the theoretical capacity of $\mathrm{Cu}\left(843 \mathrm{mAh} \mathrm{g}_{\mathrm{Cu}}{ }^{-1}\right), m_{c u}$ is the mass of $\mathrm{Cu}$ cathode $(63.55 \mathrm{~g} ; 1 \mathrm{~mol}), m_{\mathrm{LiNO} 3}$ is the mass of $\mathrm{LiNO}_{3}$ in electrolyte $(2 \times 68.95 \mathrm{~g} ; 2 \mathrm{~mol})$, and $m_{\mathrm{Zn} \text { (NO3)2 } 2}$ is the mass of $\mathrm{Zn}\left(\mathrm{NO}_{3}\right)_{2}$ in aqueous anode $(189.39 \mathrm{~g} ; 1 \mathrm{~mol})$. The $m^{1}{ }_{\mathrm{H} 2 \mathrm{O}}$ and $m^{2}{ }_{\mathrm{H} 2 \mathrm{O}}$ are the masses of water for $\mathrm{LiNO}_{3}$ dissolution $\left(100 \mathrm{~g} \mathrm{H}_{2} \mathrm{O}\right)$ and $\mathrm{Zn}\left(\mathrm{NO}_{3}\right)_{2}$ dissolution $\left(137 \mathrm{~g} \mathrm{H}_{2} \mathrm{O}\right)$, which are calculated based on their solubility at $30^{\circ} \mathrm{C}$. According to equation (4), the calculated energy density can reach $68.3 \mathrm{Wh} \mathrm{kg}^{-1}$. It should be noted that $2 \mathrm{M}$ 
a

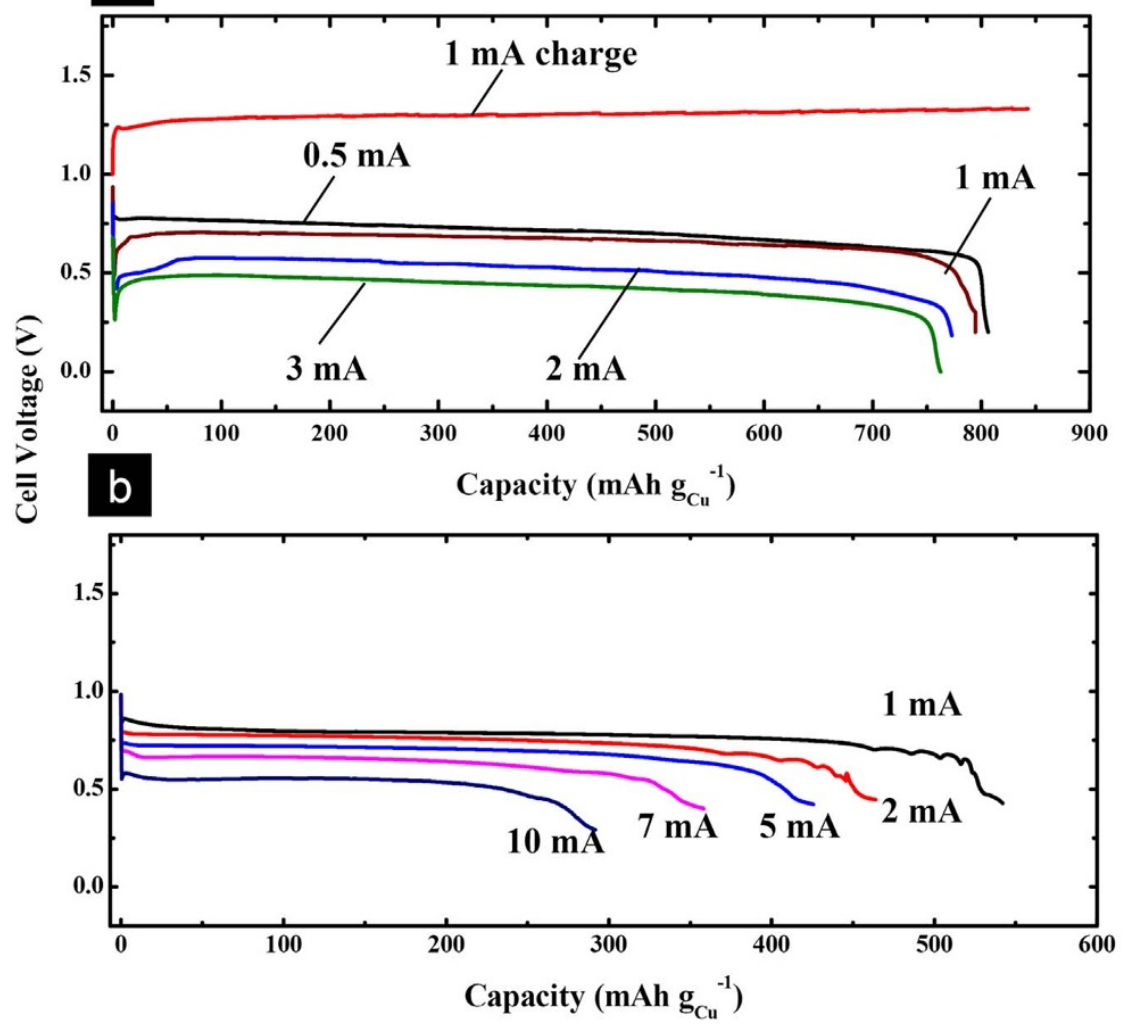

c
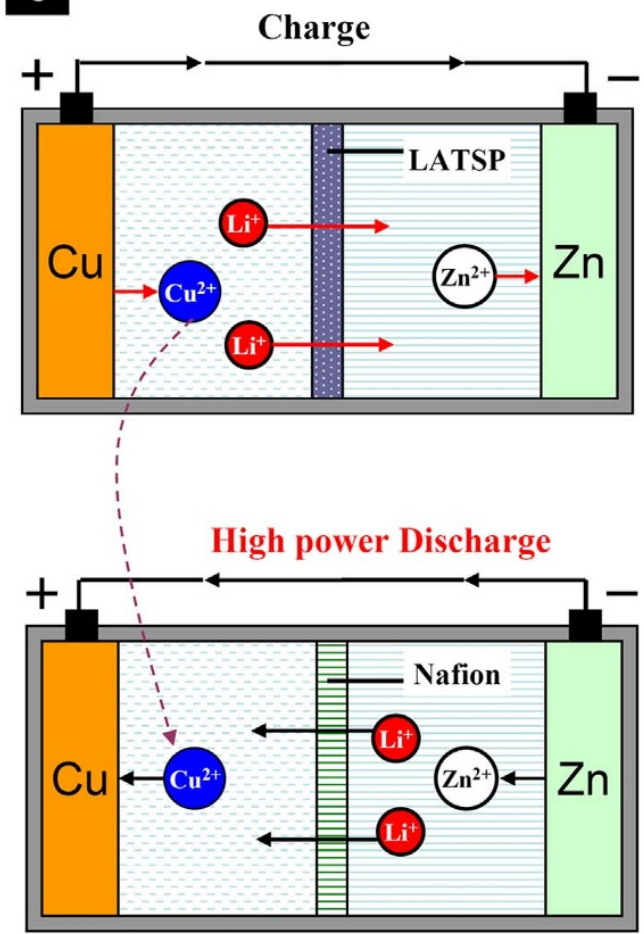

Figure $4 \mid$ Discharge curves of Zn-Cu batteries at different currents. (a) Discharge curves of LATSP-based Zn-Cu battery. (b) Discharge curves of Nafion-based Zn-Cu battery. (c) Schematic illustrating the combination application between LATSP-based Zn-Cu battery and Nafion-based Zn-Cu battery.

$\mathrm{LiNO}_{3}$ solution and $1 \mathrm{M} \mathrm{Zn}\left(\mathrm{NO}_{3}\right)_{2}$ solution were employed in our experiment to demonstrate the performance of rechargeable $\mathrm{Zn}-\mathrm{Cu}$ battery. However, the calculation of theoretical energy of the rechargeable $\mathrm{Zn}-\mathrm{Cu}$ battery is based on the solubility of $\mathrm{LiNO}_{3}$ and $\mathrm{Zn}\left(\mathrm{NO}_{3}\right)_{2}$ at $30^{\circ} \mathrm{C}$. Typically, the electrode/electrolyte material weighs about $50 \%$ of the total weight of the large-size practical battery. Thus, the practical specific energy of the new type $\mathrm{Zn}$-Cu battery

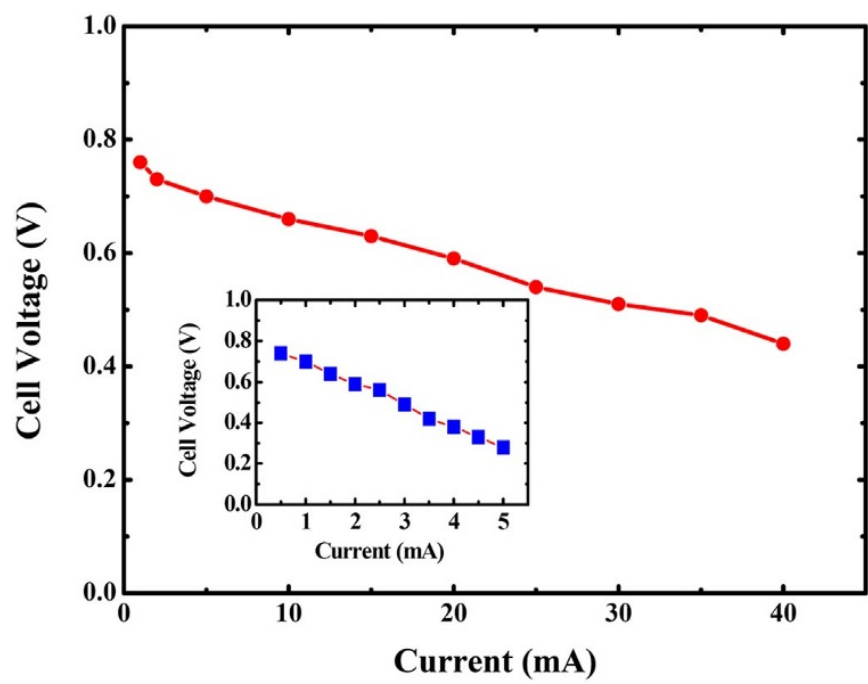

Figure $5 \mid$ Rate performance (discharge voltage vs. current) of Nafionbased $\mathrm{Zn}$-Cu battery investigated with $1 \mathrm{M} \mathrm{Cu}\left(\mathrm{NO}_{3}\right)_{2}$ solution. The inset is the discharge voltage vs. current of LATSP-based $\mathrm{Zn}$-Cu battery tested at the same condition. near $34 \mathrm{Wh} \mathrm{kg}^{-1}$ can be expected, which is compatible with commercialized lead acid battery $\left(30 \sim 40 \mathrm{Wh} \mathrm{kg}^{-1}\right)^{3,24}$ and flow battery (25-30 $\left.\mathrm{Wh} \mathrm{kg}^{-1}\right)^{3,24}$. It is more important that the electrode reactions of the battery depend on the dissolution-deposition of metallic $\mathrm{Cu}$ and $\mathrm{Zn}$, indicating that $\mathrm{Cu}$-cathode and $\mathrm{Zn}$-anode are renewable and reusable. For example, the $\mathrm{Cu}$-cathode or $\mathrm{Zn}$-anode in a used rechargeable $\mathrm{Zn}-\mathrm{Cu}$ battery can be directly recycled to fabricate a new electrode. However, for present commercialized aqueous battery (e.g. lead acid, Ni-Cd and Ni-MH batteries), the recycle of electrode materials is of a great challenge. Especially, both electrode material and electrolyte of rechargeable $\mathrm{Zn}$-Cu battery are low toxicity, which is quite important for low carbon society. Therefore, the rechargeable $\mathrm{Zn}-\mathrm{Cu}$ battery can be considered as a promising power source for large-scale energy storage. On the other hand, the charge rate (e.g. energy storage rate) of rechargeable $\mathrm{Zn}-\mathrm{Cu}$ battery is still much limited by the low conductivity of the ceramic LATSP film, and can not be offset by the above Nafion-based $\mathrm{Zn}-\mathrm{Cu}$ battery. As a response, this kind of $\mathrm{Zn}-\mathrm{Cu}$ battery may be only suitable for solar energy storage at present stage. In the further investigation, it is necessary to improve the conductivity of ion-exchange membrane and enhance the operating temperature of the battery. Especially, enhancing the operating temperature can not only improve the conductivity of the ceramic ion-exchange membrane but also increase the solubility of active materials, which thus can improve both energy and power density of the system. It should also be noted that dendrite growth inevitably occurs on the $\mathrm{Cu}$ and $\mathrm{Zn}$ electrode over cycling process. Although the short circuit hazards in the rechargeable $\mathrm{Zn}$ $\mathrm{Cu}$ battery can be eliminated because the rigid ceramic LATSP film is hardly pierced by the dendrites on electrode, the dendrite growth still could limit the efficient utilization of $\mathrm{Cu} / \mathrm{Zn}$ electrode over long-time cycling. Therefore, more researches should be done to solve the 
problem, for example, some kind of electrolyte additive might be useful to produce smooth coating during the electrodeposition.

In summary, the old Daniell cell was re-built as a stable and rechargeable battery through the Li-ion exchange film that can efficiently prevent the crossover of $\mathrm{Cu}^{2+}$. The theoretical energy density of the new type $\mathrm{Zn}-\mathrm{Cu}$ battery can reach $68.3 \mathrm{Wh} \mathrm{kg}^{-1}$ which is compatible with current aqueous rechargeable batteries. It is more important that both electrodes of the battery are renewable, reusable, low toxicity and environmentally friendly. It can be expected that this investigation not only gives a new birth for the very old Daniell cell, but also provides a new promising and green power source for largescale energy storage.

\section{Method}

Materials and Preparation of $\mathrm{Zn}-\mathrm{Cu}$ battery. The reagents [e.g. $\mathrm{Zn}$ plate, $\mathrm{Cu}$ plate, $\mathrm{Zn}\left(\mathrm{NO}_{3}\right)_{2}$ and $\mathrm{LiNO}_{3}$ ] were purchased from Sinopharm Chemical Reagent Co. Ltd (Shanghai). Zinc plate $(0.2 \mathrm{~mm}$ in thickness, $99.9 \%)$ and copper plate $(0.1 \mathrm{~mm}$ in thickness, $99.9 \%$ ) were polished before battery assembly. The $2.5 \times 2.5 \mathrm{~cm}^{2}$ ceramic lithium super-ionic conductor film (LATSP, $\mathrm{Li}_{1+\mathrm{x}+\mathrm{y}} \mathrm{Al}_{\mathrm{x}} \mathrm{Ti}_{2-\mathrm{x}} \mathrm{Si}_{\mathrm{y}} \mathrm{P}_{3-\mathrm{y}} \mathrm{O}_{12}$ purchased from Ohara Inc., Japan) with a thickness of $0.15 \mathrm{~mm}$ and a Li-ion conductivity of $10^{-4} \mathrm{~S} \mathrm{~cm}^{-1}$ was used as received. The glass microfiber filter was obtained from Whatman ${ }^{\circledR}$ Anodisc Inorganic Membranes. $2 \mathrm{M} \mathrm{LiNO}_{3}$ solution and $1 \mathrm{M} \mathrm{Zn}\left(\mathrm{NO}_{3}\right)_{2}$ solution were used as cathodic electrolyte and anodic electrolyte, respectively. Detailed information about the battery assembly was given in Figure S4.

Electrochemical Characterization. Electrochemical tests were performed on HOKUTO DENKO battery charge/discharge system HJ series (Japan) controlled by a computer. The electrochemical impedance spectroscopy (EIS) was carried out on Solartron Instrument Model 1287 in the frequency range of $10^{6}-0.01 \mathrm{~Hz}$ with the AC signal amplitude of $10 \mathrm{mV}$.

1. Boulabiar, A., Bouraoui, K., Chastrette, M. \& Abderrabba, M. A historical analysis of the Daniell cell and electrochemistry teaching in French and Tunisian textbooks. J. Chem. Educ. 81, 754-757 (2004)

2. Martins, G. F. Why the Daniell cell works. J. Chem. Educ. 67, 482-482 (1990).

3. Armand, M. \& Tarascon, J. M. Building better batteries. Nature 451, 652-657 (2008).

4. Bruce, P. G., Scrosati, B. \& Tarascon, J. M. Nanomaterials for rechargeable lithium batteries. Angew. Chem. Int. Ed. 47, 2930-2946 (2008).

5. Luo, J. Y., Cui, W. J., He, P. \& Xia, Y. Y. Raising the cycling stability of aqueous lithium-ion batteries by eliminating oxygen in the electrolyte. Nat. Chem. 2, 760-765 (2010).

6. Wang, Y. G., Yi, J. \& Xia, Y. Y. Recent progress in aqueous lithium-ion batteries. Adv. Energy Mater. 2, 830-840 (2012).

7. Li, L. J., Zhao, X. S. \& Manthiram, A. A dual-electrolyte rechargeable Li-air battery with phosphate buffer catholyte. Electrochem. Commun. 14, 78-81 (2012).

8. Li, L. J., Zhao, X. S., Fu, Y. Z. \& Manthiram, A. Polyprotic acid catholyte for high capacity dual-electrolyte Li-air batteries. Phys. Chem. Chem. Phys. 14, 12737-12740 (2012).

9. Lu, Y. H. \& Goodenough, J. B. Rechargeable alkali-ion cathode-flow battery. J. Mater. Chem. 21, 10113-10117 (2011).

10. Lu, Y. H., Goodenough, J. B. \& Kim, Y. Aqueous cathode for next-generation alkali-ion batteries. J. Am. Chem. Soc. 133, 5756-5759 (2011).

11. Zhang, T. et al. A novel high energy density rechargeable lithium/air battery. Chem. Commun. 46, 1661-1663 (2010).

12. Zhang, T. et al. Li/polymer electrolyte/water stable lithium-conducting glass ceramics composite for lithium-air secondary batteries with an aqueous electrolyte. J. Electrochem. Soc. 155, A965-A969 (2008).
13. Zhao, Y., Wang, L. N. \& Byon, H. R. High-performance rechargeable lithiumiodine batteries using triiodide/iodide redox couples in an aqueous cathode. Nat. Commun. 4, 1896-1902 (2013)

14. Zhao, Y. \& Byon, H. R. High-performance lithium-iodine flow battery. $A d v$. Energy Mater. 3, 1630-1635 (2013).

15. Zhao, Y. et al. A reversible $\mathrm{Br}_{2} / \mathrm{Br}^{-}$redox couple in the aqueous phase as a highperformance catholyte for alkali-ion batteries. Energy Environ. Sci. 7, 1990-1995 (2014).

16. Zhou, H. S., Wang, Y. G. Li, H. Q. \& He, P. The development of a new type of rechargeable batteries based on hybrid electrolytes. ChemSusChem. 3, 1009-1019 (2010).

17. He, P., Wang, Y. G. \& Zhou, H. S. A Li-air fuel cell with recycle aqueous electrolyte for improved stability. Electrochem. Commun. 12, 1686-1689 (2010).

18. Wang, Y. G. \& Zhou, H. S. A lithium-air battery with a potential to continuously reduce O2from air for delivering energy. J. Power Sources. 195, 358-361 (2010).

19. Wang, Y. G. \& Zhou, H. S. A lithium-air fuel cell using copper to catalyze oxygenreduction based on copper-corrosion mechanism. Chem. Commun. 46, 6305-6307 (2010).

20. Wang, Y. G. \& Zhou, H. S. A new type rechargeable lithium battery based on a Cucathode. Electrochem. Commun. 11, 1834-1837 (2009).

21. Wang, Y. G., He, P. \& Zhou, H. S. A lithium-air capacitor-battery based on a hybrid electrolyte. Energy Environ. Sci. 4, 4994-4999 (2011).

22. Wang, Y. R., He, P. \& Zhou, H. S. Li-redox flow batteries based on hybrid electrolytes: at the cross road between Li-ion and redox flow batteries. Adv. Energy Mater. 2, 770-779 (2012).

23. Lim, H. D. et al. Superior rechargeability and efficiency of lithium-oxygen batteries:hierarchical air electrode architecture combined with a soluble catalyst. Angew. Chem. Int. Ed. 53, 3926-3931 (2014).

24. Dunn, B., Kamath, H. \& Tarascon, J. M. Electrical energy storage for the grid: a battery of choices. Science 334, 928-935 (2011).

\section{Acknowledgments}

The authors acknowledge funding support from the Natural Science Foundation of China (21333002, 21373060), the State Key Basic Research Program of PRC (2013CB934103, 2014CB932301), Shanghai Pujiang Program (13PJ1400800), and Shanghai Science \& Technology Committee (11DZ1100207, 08DZ2270500)

\section{Author contributions}

X.L.D. and Y.G.W. designed the experiments and discussed the interpretation of results. X.L.D., Y.G.W. and Y.Y.X. discussed the results, co-wrote the paper and participated in the manuscript revision.

\section{Additional information}

Supplementary information accompanies this paper at http://www.nature.com/ scientificreports

Competing financial interests: The authors declare no competing financial interests.

How to cite this article: Dong, X., Wang, Y. \& Xia, Y. Re-building Daniell Cell with a Li-ion exchange Film. Sci. Rep. 4, 6916; DOI:10.1038/srep06916 (2014).

This work is licensed under a Creative Commons Attribution-NonCommercialShareAlike 4.0 International License. The images or other third party material in this article are included in the article's Creative Commons license, unless indicated otherwise in the credit line; if the material is not included under the Creative Commons license, users will need to obtain permission from the license holder in order to reproduce the material. To view a copy of this license, visit http:// creativecommons.org/licenses/by-nc-sa/4.0/ 